\title{
Hydrology, erosion and sediment production in a surging glacier: Variegated Glacier, Alaska, 1982-83
}

\author{
NeIL F. Humphrey \\ Department of Geology and Geophysics, University of Wyoming, Laramie, Wr 82071, U.S.A. \\ C. F. RAYMOND \\ Geophysics Program AK-50, University of Washington, Seattle, Washington 98195, U.S.A.
}

\begin{abstract}
Outlet streams of Variegated Glacier, Alaska, U.S.A., were observed before, during and after the surge of 1982-83. Measurements of discharge, suspended sediment and dissolved load in the outlet streams are presented for the years 1982-84, and comparisons are made with data from previous years. The data are interpreted to yield characteristics of the basal hydraulic system. The surging region of the glacier was underlain by a basal hydraulic zone of low water velocity and high water storage, inferred to be a distributed-flow system. The ice down-glacier of the propagating surge front was underlain by a highvelocity, low-storage zone, inferred to be a conduit system. The volume of water stored above the surge front was the major hydraulic control on the surge. Basal bedrock erosion during the surge was extreme in comparison to non-surging glaciers. The sediment output was directly proportional to the basal sliding, with a dimensionless erosion rate (meters eroded from the bed divided by meters of sliding) of order $1.0 \times 10^{-4}$. Total erosion during the 20 year surge cycle was on the order of $0.3 \mathrm{~m}$ of bedrock, with approximately two-thirds occurring during the 2 years of the surge peak, and the bulk of this during the peak 2 months.
\end{abstract}

\section{INTRODUCTION}

The characteristics of streams draining from a glacier can be used to infer the properties of the drainage system in the glacier (Collins, 1978, 1979; Tranter and Raiswell, 1991; Fountain, 1992) and coupling between the drainage system and glacier motion (Humphrey and others, 1986). In order to provide information about the evolution of the drainage system of Variegated Glacier, Alaska, U.S.A., as it changed between surging and nonsurging states, its outlet streams were observed from 1980 to 1985. A previous paper (Humphrey and others, 1986) discussed the water, sediment and solute output of the streams in the pre-surge years of 1980 and 1981. This paper presents data from the outlet streams for the period of the surge in 1982 and 1983 and after the surge in 1984 and 1985. The behavior of the outlet streams is compared for the pre-surge, surge and immediate post-surge phases.

Variegated Glacier (Fig. 1) has a surge cycle of approximately 17 years. The most recent surge occurred in 1982-83 and was extensively observed (Kamb and others, 1985; Harrison and Raymond, 1986; Raymond, 1987; Raymond and others, 1987). There were two distinct phases of the surge. Each phase started gradually in early to mid-winter and ended with a sequence of abrupt slow-downs in late June or early July in both years. During the first year of the surge, which started in January 1982, rapid ice motion was confined to the uppermost $10 \mathrm{~km}$ of the glacier. During the second phase, starting in November 1982, the surge motion propagated to the lower part of the glacier and reached the moraines of the terminal lobe left by previous surges. This phase terminated abruptly on 5 July 1983.

\section{Outlet streams of Variegated Glacier}

The locations of the major streams are shown in Figure 1. Before the surge, the \#1 (upper) stream carried most of the water and sediment from the active part of the glacier (Humphrey and others, 1986), the \#3 (lower) stream drained the ablating terminal lobe and remnant moraines of previous surges, \#2 did not exist and \#4 was a small englacial stream that was accessible in a large collapse feature (ice doline). By the end of the surge, practically all the water from the glacier flowed down the enlarged \#3 stream valley. The responses of the outlet streams to the two phases of the surge were different.

During the first phase in 1982, when surging was confined to the upper half of the glacier, the morphology and relative discharges of the outlet streams remained similar to previous years without major effects from the surge. In particular, there was no evidence of high discharges or high sediment concentrations having occurred prior to the arrival of the field party on 27 May 1982, even though surge motion started the previous winter. Remnant snow bridges over the upper stream would have recorded sediment lines from flows higher than the $1 \mathrm{~m}^{3} \mathrm{~s}^{-1}$ observed in late May. The lack of such sediment lines indicated that no significant discharge events had occurred either at the initiation of the surge 


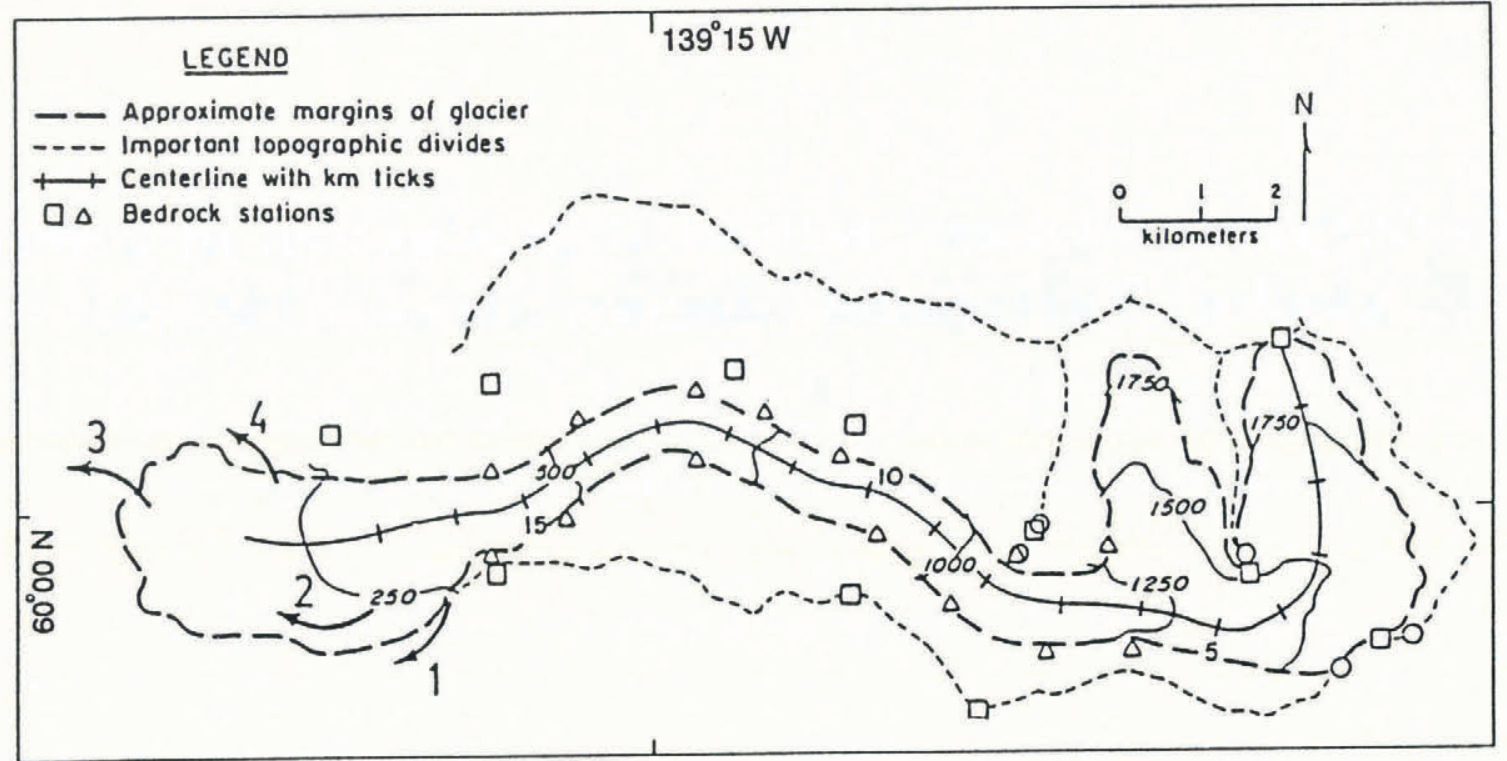

Fig. 1. Location map for Variegated Glacier, southeast Alaska. The schematic map of the glacier shows the main outlet streams, numbered 1 to 4 . Locations are referred to by their kilometric distance from the glacier head. The region above $K m$ 9 is referred to as the upper glacier.

motion or during its early development. There were, however, observable variations in sediment load and discharge related to the surge during the summer of 1982 .

During the second phase of the surge, when the surge propagated into the lower glacier, there were major alterations in characteristics of the streams. Time-lapse cameras viewed streams \#1 and \#3. On 4 February 1983, a discharge of turbid water flooded the snow-covered floor of the \#1 stream valley; two smaller floods occurred on 21 February and 21 March. No floods occurred in stream \#3. All three discharge events correlated with slow-downs in glacier velocity as observed in the upper glacier with automatic cameras. These floods deposited a layer of sand and silt debris up to $0.5 \mathrm{~m}$ thick over much of the channel of the steam. This debris, interbedded with aufeis and snow, formed the banks of the rising stream in May. Erosion of the debris created highly variable sediment discharge, unrelated to the sediment output from under the glacier ice. Most of the material discharged by the winter floods had been reworked by the end of May.

As the surge front advanced into the terminal lobe of the glacier, the outlet streams were reorganized by channel shifts caused by abrupt changes in discharge of water and sediment, with eventual invasion by moving ice. By the end of May, stream \#1 was experiencing orderof-magnitude variations in discharge and sediment flux on a time-scale of hours. In the first week of June, a new outlet (stream \#2) was formed $0.5 \mathrm{~km}$ down-glacier from the original outlet. Stream \#2 carried most of the discharge until 14 June, when the bulk of the water appeared in stream \#3. Stream \#3 has remained the major outlet stream since the surge.

\section{DATA COLLEGTION}

Obtaining data from glacial-outlet streams is difficult at the best of times. During a surge the constant disruption of the streams and the order-of-magnitude changes in the variables make both measurements and their calibration very difficult. Most of the conclusions drawn in this paper depend on order-of-magnitude types of observation or resulting calculations, and are somewhat immune to the vagaries of the data.

In 1982, the streams were observed by personnel for a short time in late May, while automatic instruments were being installed to measure water resistivity, turbidity and stage. Manual estimates of water discharge were made at this time, based on average surface velocities obtained by timing floats thrown on the water, along with width and depth measurements. Water samples were taken, to determine suspended- and dissolved-sediment loads. Water stage and temperature were also recorded, and sample measurements of water resistivity were made. These various measurements were used to provide calibration for the automated equipment.

In 1983, the streams were observed by personnel on site from 5 May to the end of July and also in late August-early September. Water discharge and stream morphology were recorded, as well as readings of water resistivity and turbidity obtained with hand-held versions of the automatic equipment. Water samples were taken each day, with some days intensely sampled ( 50 samples). Although the field-observation program was designed mainly to calibrate the automatic equipment and to gain an overview of stream behavior, the propagation of the surge into the lower reaches of the glacier prevented the effective use of the automatic equipment. Eventually, by 14 June, the extreme erosion of the stream beds ( $m$ ) and bank erosion (tens of $m$ ) caused by the large discharge fluctuations resulted in such rapid reconfigurations of the main outlet stream (\#3) that maintaining an automatic installation was abandoned.

\section{Methods for automatic recording of stream variables}

The automatic data-acquisition system used on Variegated Glacier's outlet streams before 1982 is described 


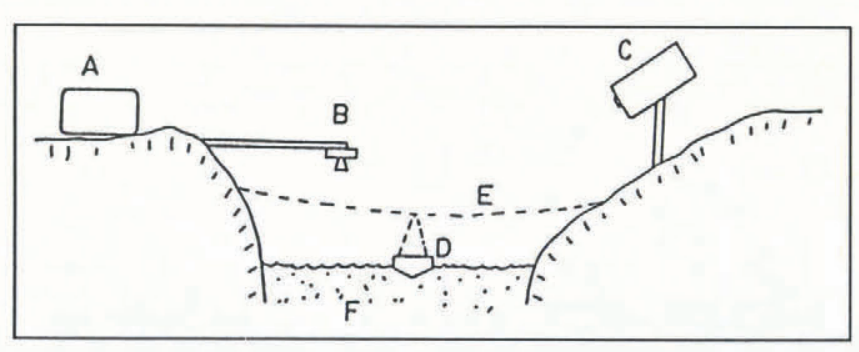

Fig. 2. Sketch of the automatic sensor system in use in 1983: A, recorder; $B$, acoustic water-stage sensor; $C$, automatic camera; $D$, floating instrument package, with turbidity and conductivity sensors; $E$, cross-stream cable; $F$, stream.

elsewhere (Humphrey and others, 1986). Improvements were made in 1982 and 1983 both to the instruments and to the instrument carrier that was placed in the stream. Two types of tethered instrument packages were hung in the stream. A schematic view of the automatic system in use during the summer of 1983 is shown in Figure 2.

In 1982, and again in the early spring of 1983, a fishlike submerged metal pod, hanging in the stream, was tethered to a steel cable stretched across stream \#1. The pod carried a light-transmittance sensor, consisting of a light source and detector to measure the water turbidity, as a surrogate for the suspended-sediment concentration. The pod also contained a conductivity cell for the measurement of the ionic-solute concentration. Signal cables carried the measurements to the automatic recording gear on the stream bank. The tethering system was designed to prevent a loss of equipment similar to the loss of the two stilling-well installations washed away during rapid channel migrations in 1981. Though one pod was still lost, in July, it was replaced and only a short interval of data lost. Data were also lost after 24 August 1982, when an ice-block impact tangled the sensor in the tethering cables.

Although the tethered-pod design was relatively robust against loss, it was not a good sensor carrier. The pod caused disturbance in the stream flow, which tended to cause formation of a mid-channel bar enveloping the instruments. Another problem seems inherent with suspension of an instrument package in a shallow active glacial stream; instruments are bombarded with floating ice blocks and also rock debris when channel bars migrate past the pod. This constant abuse appears to have caused considerable instrument drift, and as a consequence the 1982 automatic data are particularly poor in accuracy. The problem that caused the greatest data loss was water leakage into the signal cables. The resulting galvanic action caused spurious voltages on the recorded signals. Water leakage is difficult to prevent in the energeticstream environment. A partial solution was to maintain the signal currents as large as possible to mask the spurious voltages in the signal cables.

In the summer of 1983, a floating instrument pod was tethered to the cross-stream cable (Fig. 2). The float rode over passing ice blocks and was sufficiently far from the bed to avoid the worst of the rock bombardment. With the floating pod it was possible to prevent water leakage into the signal cables. The float had to be self-righting since it was often flipped by waves or ice. The major mechanical deficiency of the float is its interaction with surface waves on the stream. Certain shapes of standing waves tend to roll a float continually; this in turn winds up the tether and electrical cable. The constant flexing of the signal and suspension cables led in one case to breakage and loss of the float. Although the floating pod was not prone to promote bar formation, it could still be stranded by major channel changes.

The major instrumental difficulty with the floating pod was leakage of daylight into the turbidity sensor. This was a problem mainly at low sediment concentrations, when the relatively clear water scatters light under the float. This problem is insidious, since the spurious signal introduced by light leaks tends to be diurnal, thus contaminating the strong diurnal trend in the turbidity variations.

Time-lapse $8 \mathrm{~mm}$ cine-cameras were installed to observe the two major outlet streams (\#1 and \#3) between 1980 and 1984 (Fig. 2). The cameras were set to take one or two frames per hour and operated for 2-3 months on one set of batteries and film. The cameras ran year-round from the spring of 1982 till 1984, although there are short gaps in the winter months, caused by electronic failures or snow burial. The cameras gave an overview of stream behavior, as well as a crude record of water discharge. To gain a more accurate measure of water discharge, an acoustic ranging system was cantilevered over stream $\# 1$ and used to record water stage (Fig. 2). The ranging system is susceptible to reading errors caused by rain, grounded ice blocks or even the passage of standing waves over a traveling dune. The record is also complicated by stream-channel migration and degradation. However, the acousticranger and camera estimates of river stage complement each other, since the time-lapse camera gives a record (subjectively estimated) of daily discharge ranges, documents many channel changes and allows an estimate of discharge even during or after major channel changes, while the ranger records short-term fluctuations and stage changes that occur at night.

\section{Estimating water discharge}

Most manual and all automatic discharge estimates were based on the stream stage (height). On stream \#1, the stage was referenced to a stage-rating curve established by stream profiling, including cross-stream and vertical velocity profiles, obtained in 1980 (for technique see Leopold and others (1967)). The stream channel migrated and degraded considerably after the stagerating curve was established, but neither the overall stream gradient nor the apparent stream roughness changed significantly, except possibly at high flows. The Manning roughness parameter (see Leopold and others, 1964) was measured at $0.034 \mathrm{~m}^{-3} \mathrm{~s}$ in 1980 . No velocity profiling was done on stream \#3, but cross-sections were measured, and since it was similar to stream \#1 it was assumed to have a similar Manning roughness, which allowed us to estimate a stage-rating curve for stream \#3. The Manning roughness may have changed significantly during peak discharges of water and with the high suspended-sediment concentration and bedload-transport 
rates. These effects, along with channel aggradation and/ or degradation at high water and sediment discharges, make the values of peak water discharges poorly constrained.

During field observations, estimates of water discharge were obtained to check and modify the stage-rating curves as the streams eroded. Observations were made of stream width, depth and water-surface velocity. Watersurface velocity was estimated by timing the passage of floats thrown onto the water at different cross-stream positions to obtain a width average. At low flow the water depth was probed, while at high flow it was estimated. The most reliable way of estimating depth at high discharges is to observe the size of rolling ice blocks. This tends to produce an average depth, which along with width and average velocity yields an estimate of the cross-sectional flux. For low discharges on stream \#1, this method gave results within $20 \%$ of stream gauging with velocity meter and wading rod. At high discharges all three parameters, width, depth and velocity, are difficult to estimate and there may be much larger errors. Estimates during peak floods could be in error by $50 \%$.

As a final check on the discharge record, the $8 \mathrm{~mm}$ film record was viewed to estimate the discharge. This is subjective and rests on the familiarity of the film viewer with the stream. Compared with sections of records obtained by the other methods, the film estimates are always within $50 \%$ and usually much closer. The film records have great value in allowing a level of consistency in the discharge estimates even at times of rapidly migrating channels or channel avulsions, and before and after major channel changes.

Salt-dilution gauging to measure discharge was attempted but gave unsatisfactory results due to low total salt recovery. Dye dilution was also attempted without success. Both dilution methods were hampered by insufficient length of stream to allow thorough lateral mixing of the tracer. Neither of the major streams, \#1 or \#3, travels for more than $0.5 \mathrm{~km}$ before mixing with other streams.

\section{Galibration of suspended-sediment and solute concentration}

Measurements of water turbidity (optical transmittance) and water electrical resistivity ( $1 \mathrm{kHz}$ a.c.) were recorded in order to derive values of suspended-sediment and solute concentrations. The final stream data set contains errors deriving both from the actual measurements and from the calibration or conversion technique. The largest error in the suspended-sediment-concentration record is due to the conversion from turbidity. The error in solute concentration is dominated by the calibration error of the sensor. In addition to other sources of error, the automatic data of turbidity and resistivity are susceptible to drift of the sensors over time.

Turbidity was measured with good precision, but the conversion from turbidity to sediment concentration involved two steps that included considerable error. The first step was to estimate the sediment concentrations of a set of water samples taken concurrently with turbidity readings by determining a correlation between settledsediment depth and a smaller set of dried and weighed
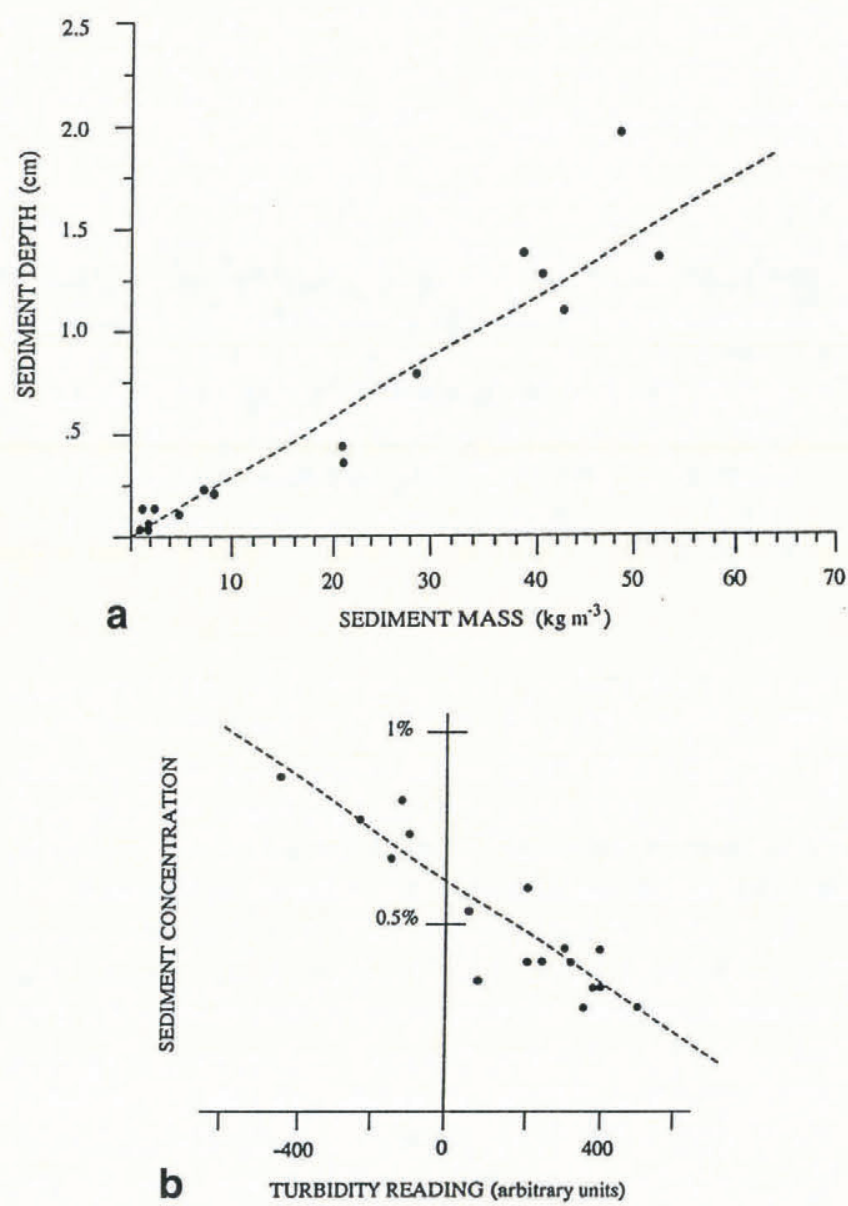

Fig. 3. a. Calibration curve for $21 \mathrm{ml}$ samples (mostly 1983-84 samples). Data from dried and weighed water samples. The water depth in the samples was $13 \mathrm{~cm}$; the line is fitted by eye. $b$. Calibration curve for AugustSeptember 1983 turbidity data from the hand-held instrument. The sediment concentration is expressed as percentage volume, obtained from concurrent water samples.

water samples. The second step was to establish a correlation between turbidity measurements and corresponding water-sample sediment concentrations estimated in the previous step 1 (for more detail see Humphrey and others (1986)). Figure 3 shows two typical calibration curves, illustrating the conversion process. The scatter in the plots indicates the magnitude of the errors. An additional error was introduced by using settled-sediment volume as a measure of sediment mass. The volume/mass ratio was found to be biased by the sediment-size distribution; finer distributions settled with greater included porosity. This is a probable cause of much of the scatter in Figure 3a.

The hand-collected water samples used for estimating the suspended-sediment concentration were not completely representative of stream conditions. They were obtained by dipping sample bottles into the stream near the bank, a technique which biases the sample toward the smaller-sized fraction because the water flow is less turbulent near the banks and some of the larger-sized particles can settle out of suspension. In the energetic Variegated Glacier streams this error is negligible for the small $(<10 \mu \mathrm{m})$ particles, but the larger (especially $>100 \mu \mathrm{m})$ particles that settle rapidly are poorly sampled. 


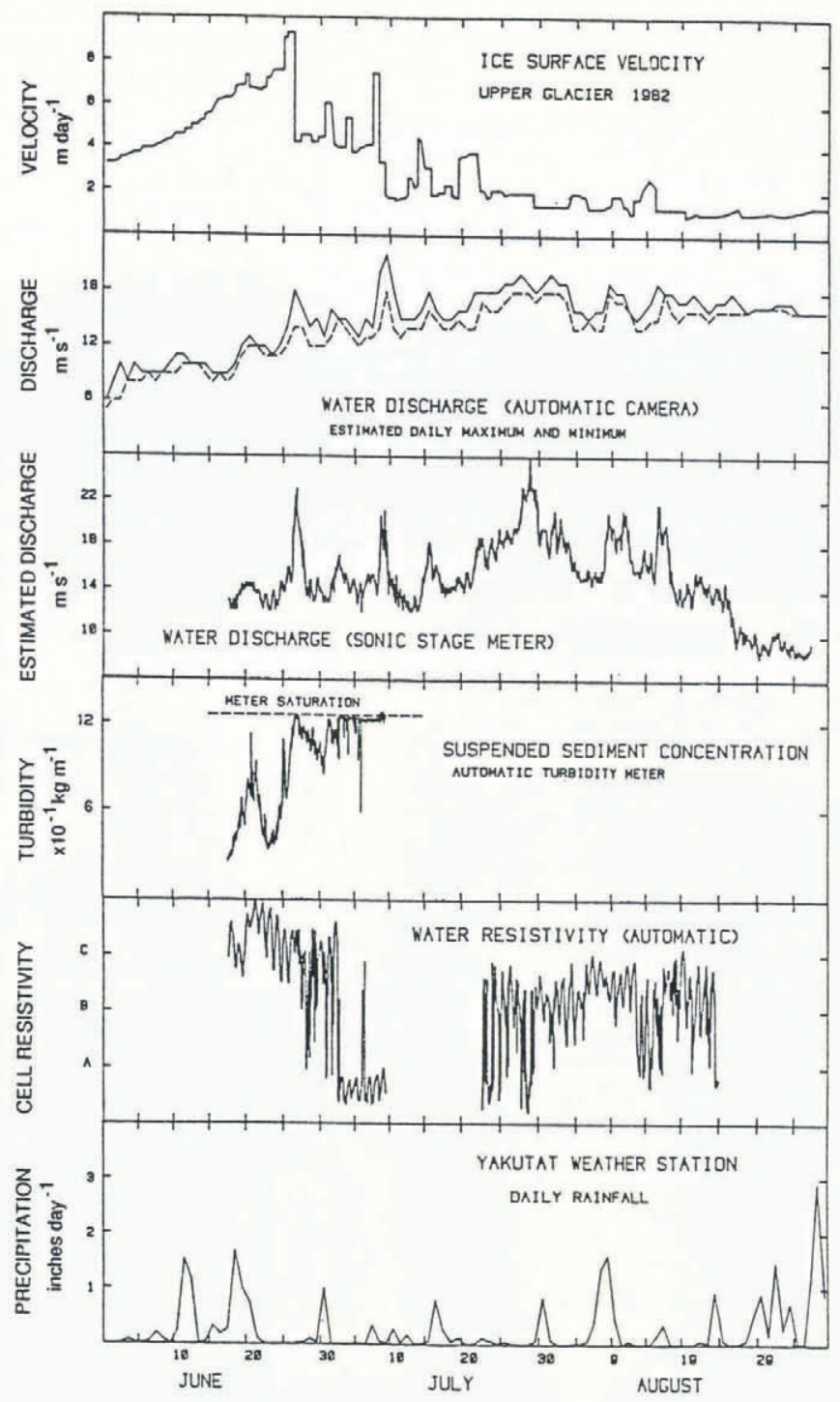

Fig. 4. Measurements from the main (\#1) stream, 1982: a. Surface ice velocity, upper glacier section (from Kamb and others, 1985); $b$. Water discharge estimated from camera record; $c$. Water discharge estimated from waterstage record; $d$. Suspended-sediment concentration estimated from turbidity; $e$. Water-resistivity record; by comparison with other data the midpoint of the scale $(B)$ is of order $5 \times 10^{-2} \mathrm{~kg} \mathrm{~m}^{-3}$, and the range (points $A-C$ ) is of order $10^{-2} \mathrm{~kg} \mathrm{~m}^{-3} ; f$. Precipitation at Yakutat weather station ( $\sim 60 \mathrm{~km}$ from the glacier).

Conversion and calibration of the water resistivity to obtain the dissolved concentration depend on both the ionic-species profile and the temperature of the water. The ionic-species profile was based on a sample of 1980 stream water (mostly $\mathrm{Ca}^{+}$and $\mathrm{CO}_{4}{ }^{-}$(Humphrey and others, 1986)). The ion profile was not monitored and could have been variable. Stream temperature was monitored and was always within $0.2 \mathrm{deg}$ of freezing. Potential errors in the dissolved concentration were small compared with potential errors in the measurement of water discharge or suspended-sediment concentration. An exception occurred in 1982 when the automatic sensor was lost before calibration. An approximate calibration was based on an extrapolation of measurements taken a week prior to the start of automatic measurement.

\section{SURGE HYDROLOGY}

\section{Surge slow-down in June-July 1982}

The surge started early in 1982, but there was no evidence on the snow-covered stream banks of high-discharge or suspended-sediment events prior to the arrival of the field party in May. Effects of the surge in the upper part of the glacier were first noted in the outlet streams during the time of maximum velocity in June and in particular during the irregular slow-down in late June and early July. Figure 4 shows features of the glacier motion and discharges from stream \#1 for the summer of 1982 . The steam parameters are derived from the automatic recording system, and may have considerable errors as discussed above. The turbidity meter was calibrated the previous year and checked only at the very beginning of the record.

Figure 4a shows a composite record (from Kamb and others, 1985) of the ice-surface velocity in the upper glacier, measured $\sim 8 \mathrm{~km}$ from the glacier head. Several velocity slow-downs are shown; the two largest occurred on 26 June and 8 July. Figure $4 \mathrm{~b}$ shows the discharge of the \#1 stream as estimated from the camera record. Figure 4c-e gives the automatically recorded data on stream discharge, turbidity and resistivity. The stream sensor was lost on 9 July and a new one installed on 22 July, but the turbidity meter was not reconnected. The lost sensor was not calibrated for resistivity (without the sensor it is not possible to calibrate). The data from the lost turbidity sensor are displayed with a calibration based on three water samples at the very beginning of the record and the meter's calibration from the previous year (the turbidity meter was the same as used in 1981).

The precipitation at Yakutat (about $60 \mathrm{~km}$ from the glacier) is shown in Figure $4 \mathrm{f}$ for comparison with stream discharge and glacier sliding. It appears that neither the stream discharge nor the glacier motion is driven primarily by precipitation inputs, although water discharge increased during clear, warm weather and sometimes during major storms. Based on the size of the Variegated hydrologic drainage-basin size, a discharge increase of $\sim 3 \mathrm{~m}^{3} \mathrm{~s}^{-1}$ would be expected from every inch $(2.5 \mathrm{~cm})$ of rain, averaged over a day.

The large, short-duration peaks in water discharge seen in Figure 4b-c, are correlated with glacier slowdowns. Of particular interest are the major slow-downs on 26 June and 8 July. The major ice-velocity slow-down on 26 June was accompanied by high water discharge and a sharp rise in sediment concentration. This was also true for the slow-down on 8 July. (Although the turbidity meter was failing, an excursion to higher turbidity is shown on 8 July; this is probably real.) Table 1 shows the timing of the slow-downs of 26 June and 8 July and includes two minor slow-downs that occurred on 20 June and 1 July. These four slow-downs were chosen because they occurred during the time that the turbidity meter was working. In addition, they are within the important period from 15 June to 10 July, during which the surge phase of 1982 peaked and then slowed. Table 1 summarizes the time relations between the changes in ice motion and in peaks of seismic noise, discharge and sediment. Three of the slow-downs show a strong water- 


\begin{tabular}{|c|c|c|c|c|c|}
\hline $\begin{array}{l}\text { Date, } \\
\text { event size }\end{array}$ & $\begin{array}{l}\text { Time of ice-velocity } \\
\text { change (upper glacier) }\end{array}$ & $\begin{array}{c}\text { Seismic-noise } \\
(F+13) \text { peak time }\end{array}$ & $\begin{array}{c}\text { Water-discharge } \\
\text { peak time }\end{array}$ & $\begin{array}{l}\text { Turbidity peak } \\
\text { time }\end{array}$ & Time lag "* \\
\hline $\begin{array}{l}\text { 19-20 June } \\
\text { (minor) }^{\dagger}\end{array}$ & $\begin{array}{c}10.00 \\
\text { (20 June) }\end{array}$ & $\begin{array}{l}12.00-24.00 \\
\text { (19 June) }\end{array}$ & $\begin{array}{l}23.00 \text { (19 June) } \\
-22.00 \text { (20 June) }\end{array}$ & $\begin{array}{l}\text { 02.00-24.00 } \\
\text { (20 June) }\end{array}$ & $\sim 0$ \\
\hline $\begin{array}{l}26 \text { June } \\
\text { (major) }\end{array}$ & $\sim 10.00$ & 10.00 & $14.00-20.00$ & $04.00-24.00$ & $\sim 8 \mathrm{~h}$ \\
\hline $\begin{array}{l}1 \text { July } \\
\text { (minor) }\end{array}$ & $12.00-18.00$ & $\sim 00.00$ & 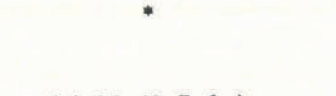 & $02.00-12.00$ & negative \\
\hline 8 July & $12.00-14.00$ & 12.00 & $\begin{array}{c}14.00 \text { (8 July) } \\
-12.00 \text { (9 July) } \\
\text { peak at } 18.00 \text { (8 July) }\end{array}$ & $\begin{array}{c}15.00 \text { (8 July) }^{\ddagger} \\
-02.00{\text { (9 July })^{\ddagger}}^{\text {( }}\end{array}$ & $\sim 5 \mathrm{~h}$ \\
\hline
\end{tabular}

** Time from velocity change to water-discharge peak.

${ }^{\dagger}$ Weak peak, water and turbidity may relate to precipitation (see text).

* Peak seen on camera record but not by acoustic ranger.

$\ddagger$ Meter saturation.

discharge signal. The slow-down of 1 July does not show up on the acoustic ranger but shows up on the camera record; this may be a result of the heavy rain, which may have confused the acoustic ranger with spurious reflections. The slow-down on 20 June was minor, and the water discharge and turbidity may be correlated with the $\sim 2$ in $(5 \mathrm{~cm})$ of precipitation that fell on 18-19 June. Indeed, the small slow-down may be related to the precipitation, and is one of several indications of a weak association between glacier motion and precipitation or meltwater input. The inference from the data is that the time delay between the surge slow-downs and the loss of water is small; there may be a $5-10 \mathrm{~h}$ delay in the peak discharge, but an increase in discharge is usually seen before the slow-down starts. There is no noticeable delay between the water and sediment pulses.

\section{Correlation between ice motion and water and sediment discharges}

Figure 4 shows a correlation between the velocity or velocity changes in the upper, surging part of the glacier and the water and sediment output. However, Table 1 shows that, unlike the 1980-81 mini-surges (Raymond and Malone, 1986; Humphrey and others, 1986; Kamb and Engelhardt, 1987), there is no precise relationship between the timing of the ice slow-downs and the peak release of water. Correlation is also lacking between peak velocity and water discharge. In general, the water discharge and sediment concentration start to rise several hours before the ice slow-down, but the high-water and sediment fluxes are not consistently related to the slowdown itself. Two possible interpretations are explored: (1) the slow-down events are mechanistically related to a release of water starting before the slow-down, and within a few hours the water is seen at the outlet stream; (2) the water and sediment are directly related to the high sliding velocities, not the slow-downs, and the lag time of the basal flow system is $12-24 \mathrm{~h}$.

Since the time relationship between the ice-velocity and discharge peaks is even less consistent than the relationship between the slow-downs and the discharge peaks, (1) is more plausible than (2). The lags are of the order $5-10 \mathrm{~h}$ and therefore comparable with the time delays seen during the mini-surges of 1980-81; these were shown to be compatible with relatively rapid water flow in a basal water conduit under the lower glacier, and a slower $\left(\sim 0.1 \mathrm{~m} \mathrm{~s}^{-1}\right)$ flow system above $\mathrm{Km} \mathrm{10}$. However, the timed data in 1982 are poorly defined and the details are not investigated further.

The slow-down of 26 June was associated with a major release of water of order $10^{6} \mathrm{~m}^{3}$, above the background discharge. If the water came from storage under the upper glacier where the slow-down occurred, then it represents $0.1-0.2 \mathrm{~m}$ of water thickness averaged over the actively surging area. The slow-down on 8 July released a little less. The amount of sediment released by the $26 \mathrm{June}$ slow-down was of order $10^{7} \mathrm{~kg}$. This could be viewed as a layer of debris somewhat thicker than $1 \mathrm{~mm}$ evacuated from the area of the surge zone.

The resistivity record shown in Figure 4e has a major shift on 2 July which is probably evidence of damage to the sensor. Even though the record is uncalibrated and subject to drift, it has a definite diurnal signal. There is some indication that the size of the diurnal signal increased after the slow-downs of early July. The diurnal signal implies that a significant amount of surface meltwater was entering the basal system (Collins, 1981; Humphrey and others, 1986). This meltwater may have originated from the extensive ablation zone between the surge zone (above $\mathrm{Km} \mathrm{10)}$ and the outlet stream (Km 16.5).

There are differences between the 1982 and pre-surge behaviors. In 1982 there was a distinct correlation between the discharge and the suspended sediment (Fig. 4). Prior to the surge there was little correlation (Humphrey and others, 1986). Furthermore, in 1982 a strong correlation existed between the ice motion and the water discharge. This correlation was not seen in previous years; indeed, the major ice-motion events (mini-surges) 
showed a strong correlation with sediment discharge, and only a weak and delayed correlation with water discharge. However, the pre-surge ice velocities were only a fraction of the surge velocities and their effects could have been correspondingly small and masked by diurnal and other fluctuations in the stream record.

\section{Second phase of the surge, 1983}

In 1983, the surge motion in the ice moved down-glacier toward the terminus. The progression of the surge front into the ice of the lower glacier was expressed spectacularly in the outlet streams by water-discharge events carrying large amounts of bedload. For example, a small water flood of about $5 \mathrm{~m}^{3} \mathrm{~s}^{-1}$, lasting for $<6 \mathrm{~h}$ on the morning of 16 May, deposited at least $500 \mathrm{~m}^{3}$ of gravels within $80 \mathrm{~m}$ of the outlet. Included in the debris were blocks of frozen sediment or dirty ice which apparently had over $50 \%$ sediment content. These bedload-rich floods caused rapid aggradation of the stream bed and stream avulsion. The aggradation led to leakage from stream \#1 over and through a low saddle of remnant ice and to the establishment of several flow paths in the region of stream \#2. At the end of May the surge front arrived at the outlet of stream \#1. Water discharge became fitful as the ice above the steam portal deformed and started sliding. By 3 June most of the flow of stream \#1 had been diverted to stream \#2. The flow was subglacial or englacial until it upwelled at the supraglacial head of stream \#2.

The turbid water that issued from stream \#2 disappeared into a relic and partially exhumed subglacial (or englacial) water system that could be traced downglacier as a series of collapse features in the remnant ice of previous surges. On 3 June the collapse features contained turbid water at levels that decreased progressively downglacier, thus implying both a connected system and a potential gradient leading from stream \#2 to \#3. By the first week of June, the water output from the glacier, including the minor englacial stream \#4 and all the water from stream \#2, exited at stream \#3. Exceptions were short-lived but significant. Overflow floods of up to $5 \mathrm{~m}^{3} \mathrm{~s}^{-1}$ occurred at the site of stream $\# 1$ at times when water was observed leaking out of many locations at the surge front, implying high subglacial water pressures. Also the glacial connection from stream \#2 to \#3 was temporarily blocked, causing a lake to form and the diversion of water over a saddle to the lower reaches of stream \#1.

Stream \#2 was observed closely from 4 June until its destruction by the surge bulge on 14 June. Although the stream banks were composed of morainal material, the bed was observed to scour to stagnant buried ice. The stream erratically discharged water and sediment, and at times discharged blocks of bubbly ice. Ice chips of approximately $1 \mathrm{~mm}$ diameter were common in the water samples. These did not resemble frazil ice. (No ice chips were seen in water samples in any of the streams before 1983, although ice blocks were fairly common at high discharges in stream \#1 in previous years.) The ice content in the water was estimated to be of order $10^{-4}$ by volume. The channel increased in discharge from 4 to 8 June, but the stage decreased. This was a result of erosion
DISCHARGE AND SEDIMENT LOAD OF OUTLET STREAMS
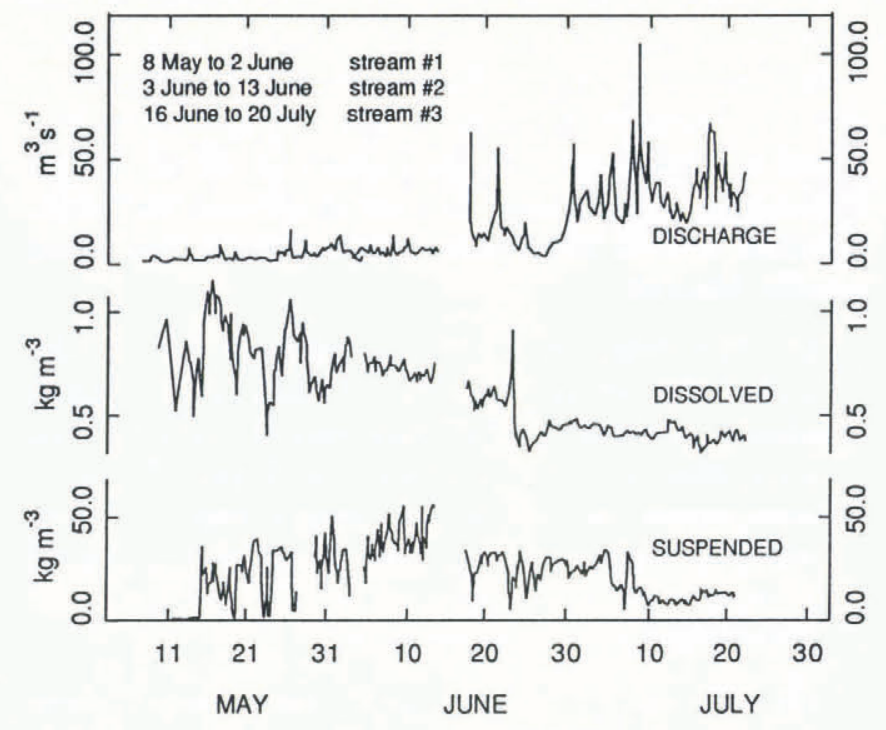

Fig. 5. Manual measurements from the outlet streams during 1983. The time period from 8 May to 20 July encompasses the peak of the surge motion. The surge stopped on 4-5 July.

of the bed presumably due to melting, although the temperature of the stream was always $<0.5^{\circ} \mathrm{C}$. A major bedload event on 8 June left a lag of cobbles on the ice bed, and subsequent bedload lodged and infilled the channel. By 9 June the surge bulge was approaching stream \#2, and the water flow showed signs of being constricted under the ice. There were several very noisy bedload-transport events, water discharge fluctuated on a 2 min time scale, and sometimes entrapped air was seen upwelling from the outlet. By 12 June the outlet was described in field notes as a bedload volcano, and it constructed a cone of debris $2 \mathrm{~m}$ above the stream.

On 14 June observations were switched to the \#3 (lower) stream. Large discharge events flooded stream \#3. Some of these were accompanied by considerable bedload which caused channel aggradation, while other floods caused up to $4 \mathrm{~m}$ of channel erosion. The surge termination on 5 July was accompanied by large water discharge, but larger floods occurred subsequently, notably on 8 July. The drainage morphology has stayed the same since the end of the surge, with the former main stream (\#1) draining only the moraines on the south side of the glacier. By 1984, stream \#3 had established a $5 \mathrm{~m}$ deep valley, walled by moraine debris and old ice and floored by lag boulders.

Figure 5 shows data from 7 May to 21 July that were acquired manually in the field. This period encompasses the peak of the surge motion and its cessation on 4-5 July. Included also in this time period are the cyclic slow-down events that propagated down-glacier (Kamb and others, 1985). Before 14 June, the data were taken from the upper (\#1) stream that was identified in Humphrey and others (1986) as draining the upper glacier; the water sampled is only part of the total discharge. After 14 June, the data were taken from streams \#1, \#2 and \#3 with the high sampling density focused on stream \#3. The record is representative of the total outflow of the glacier. Since the surge had traversed most of the glacier by 14 June, there 
is no need to distinguish between water originating in the upper glacier and that from the lower glacier in the subsequent data. The erratic sediment and solute concentration in May is fairly typical of the beginning of a melt season with low water discharges; however, the size of the data excursions, particularly for the suspended concentration, is atypical. This record of water discharge, sediment output and solute concentration has three notable features:

(1) The surge termination is reflected only in the sediment-concentration record; however, a peak similar to those of the surge record occurred two days after the surge stopped on 5 July. Detailed examination of the records shows that all three variables show a rapidly developing diurnal signal starting at the surge cessation. No diurnal signal was discernible prior to the cessation.

(2) The solute concentration shows the typical decrease in concentration as the melt season advances; however, it seems to reach a constant low level on 23 June, 2 weeks before the end of the surge, and thereafter shows no diurnal variation until 6 July. The beginning of the diurnal signal is the only suggestion of the end of the surge.

(3) The water-discharge record shows a large increase in total discharge continuing unabated after the cessation. The flow remains $\sim 50 \%$ larger than typical summer discharges for over 2 weeks after the surge. The flow was still somewhat high when observed at the beginning of September, but this may have been due to particularly rainy weather. The water represented by the outflow after the surge is of order $1 \mathrm{~m}$ over the entire glacier area. This seems an unreasonably large value to represent basal storage of all water, and is therefore suggestive of englacial storage of water. Further indications of englacial storage were the two small, turbid marginal lakes formed during the peak of the surge, and turbid water in a crevasse reported in Kamb and others (1985). The discharge of water following the surge was as chemically dilute as the water released during the surge, and is also an argument for englacial storage, since water stored at the bed would be expected to be enriched with solutes. Considerable englacial storage of water seems plausible considering the shattered nature of the ice at the peak of the surge. Although the observed crevasses were on the surface, the high basal water pressures and deviatoric stresses (Kamb and others, 1985; Raymond and others, 1987) provided ideal conditions for the formation of basal crevasses. As an alternative, the increased discharges may have been largely a result of the increase in melting of the highly crevassed glacier surface.

The surge cessation on 3-5 July cannot be identified by a change in the structure of the discharge record, although it is marked by a major peak in water discharge. However, the automatic cameras did show a definite change in stream characteristics at the surge termination. Before the surge stopped, floods both eroded and aggraded, but afterwards floods only eroded. This implies that although the sediment concentration remained elevated after 5 July, the bedload component of the sediment discharge dropped after the termination of the surge.

Figure 6 summarizes data taken during the peak of the surge. It covers the time from the destruction of stream \#2 and the diversion of all the outflow to the lower stream on 16 June and ends on 20 July after the surge termination. It includes several post-termination stream events that had no correlation with glacier-motion events. Figure $6 \mathrm{a}$ shows the ice-surface velocity near the middle of the glacier (from Kamb and others, 1985). The major feature of the velocity is the series of major velocity slow-downs, which are part of a longer series of pulses in surge velocity. The pulses tended to grow in amplitude towards the end of the surge, culminating in the termination slow-down. They propagated down-glacier at a speed of $\sim 600 \mathrm{~m} \mathrm{~h}^{-1}$ (Kamb and others, 1985). After 19 June, there was a

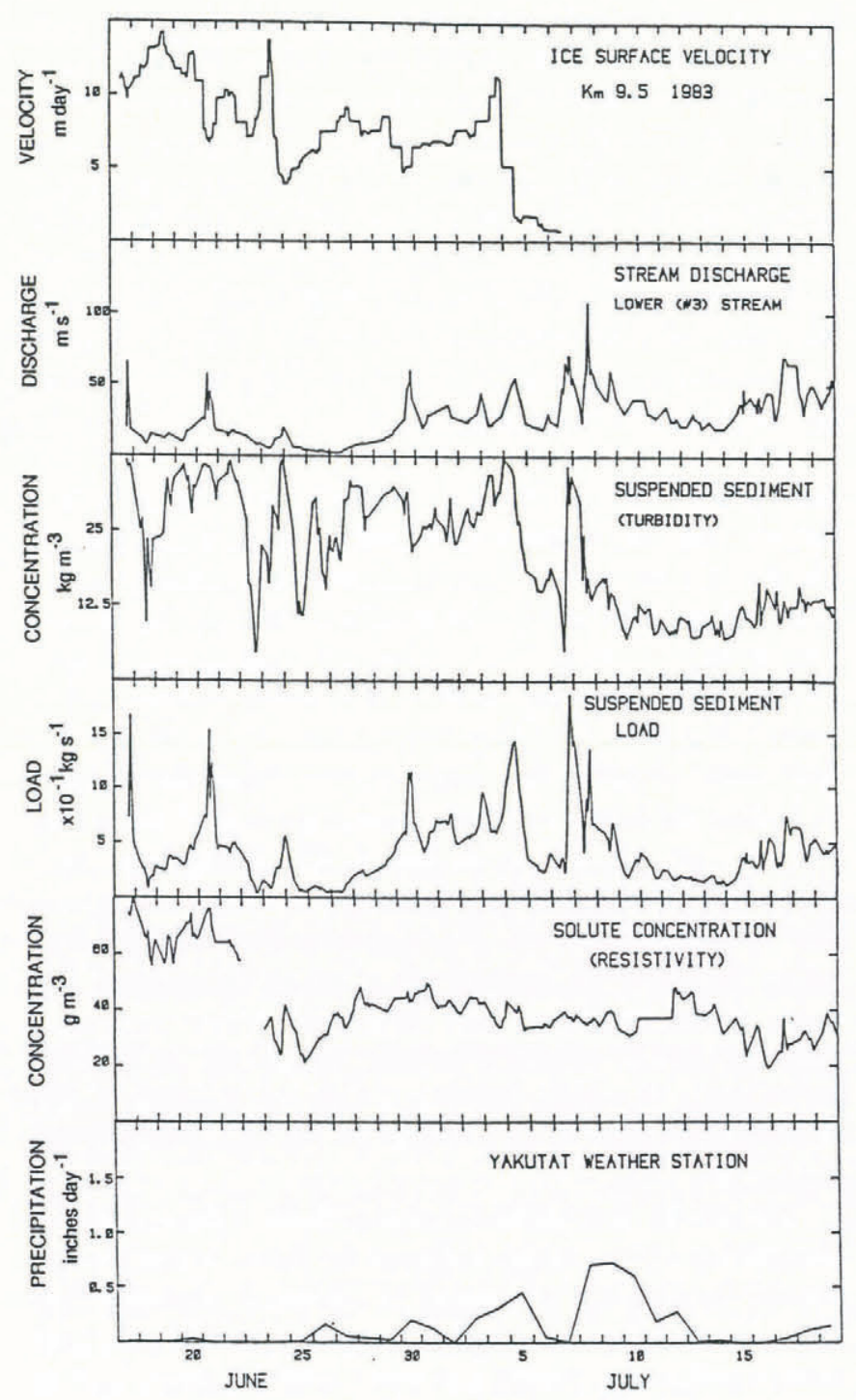

Fig. 6. Measurements from stream \#3 during 1983: a. Surface ice velocity at $K \mathrm{~m} 9.5$ (from Kamb and others, 1985); b. Water discharge estimated by observer; c. Hand measurements of turbidity, converted to suspended-sediment concentration; d. Suspended-sediment load; e. Dissolvedsediment concentration, from hand measurements of electrical resistivity; $f$. Precipitation at Yakutat weather station ( $\sim 60 \mathrm{~km}$ from the glacier). 
quasi-periodic oscillation in speed on the upper glacier with a period of $\sim 40 \mathrm{~h}$.

The signals associated with the slow-downs in ice motion can be identified in the suspended-sediment concentration and the water discharge, as shown in Figure 6a-d. Unlike in 1982, when the data were insufficient to relate variations in the stream unequivocally to ice slow-downs (as opposed to ice velocity), in 1983 the relationship between the slow-downs and the stream discharge is clear. From 17 June to the surge cessation on 5 July, most slow-downs have associated major-discharge peaks. A typical peak was of order 30$50 \mathrm{~m}^{3} \mathrm{~s}^{-1}$ and lasted about half a day. This means a water flow of $10-30 \mathrm{~m}^{3} \mathrm{~s}^{-1}$ above background levels, which implies a water loss of order $0.1 \mathrm{~m}$ averaged over the glacier. In between the slow-downs, particularly at the end of June, the water flow was actually below typical discharges, implying a recharge of storage in and under the glacier. The lag between slow-downs and waterdischarge events is between 2 and $12 \mathrm{~h}$ from the peak in the velocity slow-down to the peak in water discharge; this is tabulated for six slow-downs in Table 2. The water discharge begins to rise about $12 \mathrm{~h}$ or more before the peak. The time delay from peak to peak implies a watersignal velocity of about $1 \mathrm{~km} \mathrm{~h}^{-1}$; this appears to be somewhat faster than the propagation velocity of the velocity anomalies themselves $\left(\sim 600 \mathrm{~m} \mathrm{~h}^{-1}\right)$, but timing is not well enough defined to determine if this difference is significant.

The record of ice velocity, including slow-downs, was cross-correlated with the record of sediment concentration in order to investigate dominant time delays in the basal-sediment transport system. There is a strong correlation between velocity and sediment peaks with a lag of $6 \mathrm{~h}$. This delay has to be regarded with some suspicion, since the record is short and one or two large peaks may dominate the correlation. In 1982 the turbidity peaks, not the velocity peaks, appeared to be associated with slow-downs; however, a cross-correlation of the 1983 data between the derivative of the speed and the sediment concentration shows only a weak peak at a lag of about $4 \mathrm{~h}$. This result implies that 1983 sediment concentration was best associated with high velocity, and the water discharge with the slow-downs; this can be recognized in the data by overlying Figure $6 \mathrm{~b}$ on a, and Figure $6 c$ on a. Figure $6 b$ and $c$ show sediment concentration rising before water discharge, as also implied by the crosscorrelation results. Although sediment concentration tends to follow ice velocity, sediment load (Fig. 6d) is

Table 2. Delay times between glacier slow-down, observed $\sim 8 \mathrm{~km}$ above the \#3 stream, and observed water-discharge peak, 1983. Times have a \pm error of several hours due to spacing of measurements and broadness of peaks

\begin{tabular}{lrrr}
\hline Date & Delay & Date & Delay \\
\hline 17 June & $2 \mathrm{~h}$ & 30 June & $12 \mathrm{~h}$ \\
21 June & $5 \mathrm{~h}$ & 3 July & $10 \mathrm{~h}$ \\
24 June & $8 \mathrm{~h}$ & 5 July & $8 \mathrm{~h}$
\end{tabular}

controlled by large peaks in water discharge and thus is correlated with glacier slow-downs. The short lag of $6 \mathrm{~h}$ between the sediment concentration and ice velocity implies that the turbidity velocity is greater than the water-discharge wave velocity. This inference is speculative, since errors in the cross-correlation may be larger than the time-lag differences.

After the surge termination, there is no obvious connection between the ice motion and the stream, although a mini-surge-type event on 24 July (Kamb and others, 1985) did coincide with a discharge event. The major water-discharge event on 8 July did not coincide with changes in ice motion and may have been related to the weather. The amount of water released by the event was an order of magnitude more than the rain input to the glacier (see Fig. 6f); however, the flood may have been triggered by the rain input.

One of the most noticeable features of the stream behavior is the lack of a diurnal signal in the water discharge, suspended sediment and solutes during the peak of the surge. Soon after termination a growing diurnal signal is seen and by September (not shown) there was a strong diurnal signal in all stream variables. Despite the surge motion, the major source of basal water was still the diurnal meltwater input. For this diurnal signal to be completely damped requires water storage and slow water velocities. Velocities less than $\sim 0.5 \mathrm{~km} \mathrm{~h}^{-1}\left(0.15 \mathrm{~m} \mathrm{~s}^{-1}\right)$ would retard the meltwater from the upper parts of the glacier, so that the water arrived at the terminus area during the night when no meltwater is arriving from the lower glacier. This places only an upper value on the basal-water velocity; any lower velocity will also dampen the diurnal signal. This calculation of a water velocity somewhat less than $\sim 0.15 \mathrm{~m} \mathrm{~s}^{-1}$ can be compared with the water velocity measured during the surge with dye tracing (Brugman, 1986) of $0.02 \mathrm{~m} \mathrm{~s}^{-1}$ and with the propagation velocity of the ice slow-downs of $\sim 0.1 \mathrm{~m} \mathrm{~s}^{-1}$ (Kamb and others, 1985).

The solute concentration shown in Figure 6e shows little relation to the water discharge, sediment concentration or ice velocity. The gap in the data on 23 June is a result of moving the measurement location; however, the drop in solute concentration which occurs at that time is thought to be real, and remains an enigmatic feature of the record.

\section{Post-surge stream characteristics}

Figure 7 shows data from stream \#3 for part of June and July 1984, during which no surge motion occurred. These data provide a comparison with surge conditions. The data show a strong diurnal signal in all the variables, discharge appears to be back to pre-surge averages, but suspended-sediment concentration is 4 times as high as in 1980. This high suspended-sediment concentration is viewed as a relic of the surge and may represent continued flushing of sediments disturbed or mobilized by the surge. The water discharges of stream \#3 in 1984 were approximately equivalent to the total discharges of streams \#1 and \#3 in 1980-81.

The solute concentration in 1984 was in the range 40 $60 \mathrm{mg} \mathrm{l}^{-1}$, which is similar to that seen in 1980-81. At the end of the surge the solute concentration had dropped to 


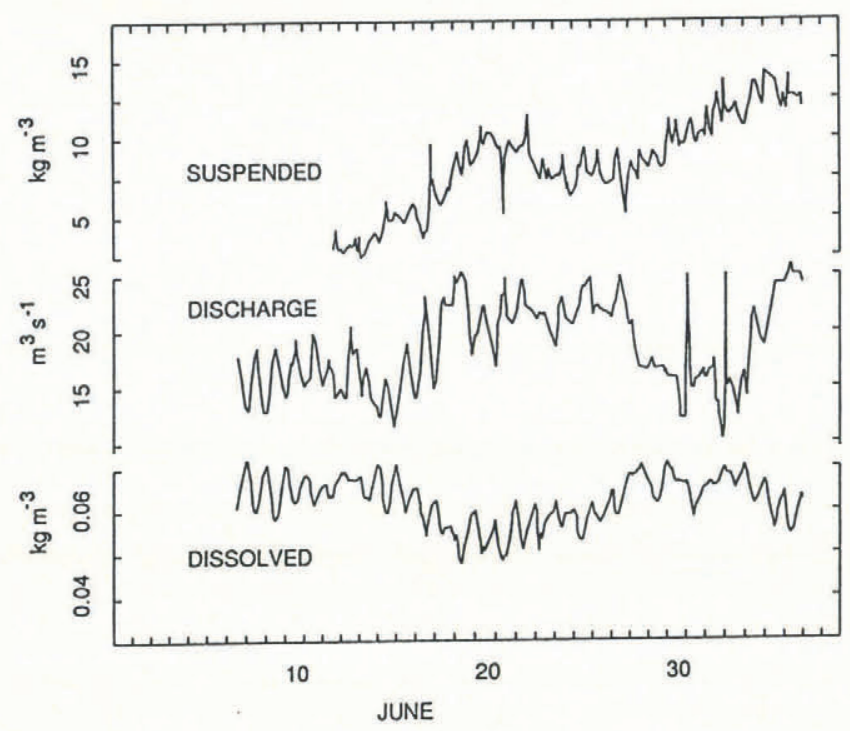

Fig. 7. Measurements from stream \#3 during 1984. The data were obtained manually from 7 June to 6 July.

a range of $20-50 \mathrm{mg} \mathrm{l}^{-1}$. As was pointed out above, the dilute water released after the surge cessation suggests that there was considerable release from englacial as opposed to subglacial storage. Water released from 24 June to $5 \mathrm{July}$, the last 10 days of the surge, was dilute compared to the pre- and post-surge data, and may suggest that a significant amount of englacially stored water was released as early as $10 \mathrm{~d}$ before the surge stopped.

\section{BEDROCK EROSION}

During the last 2 weeks of June 1980, the suspendedsediment output from the glacier was about $10 \mathrm{~kg} \mathrm{~s}^{-1}$. During the last 2 weeks of June 1983, the output was $>500 \mathrm{~kg} \mathrm{~s}^{-1}$. If the sediment output over the entire nonsurge period is assumed to have been similar to the sediment output in 1980 (possibly a liberal estimate), then in the 15 non-surge years of a 17 year surge cycle, the total suspended-sediment output was about $3 \times 10^{9} \mathrm{~kg}$, or $0.05 \mathrm{~m}$ of bedrock removed from the entire bed of the glacier. This estimate is based on the assumption that most of the sediment is evacuated each year in 3 summer months, and that the erosion rate in late June is typical of the summer. The total output of suspended sediment during the two surge years was about $6 \times 10^{9} \mathrm{~kg}$ or $0.1 \mathrm{~m}$ of bedrock, with the bulk of the sediment being flushed out in the last month of the surge. These estimates do not include bedload.

During the surge, significant amounts of rock were evacuated from the glacier as bedload in the outlet stream. The subjective impression of the stream observers was that the proportion of sediment carried as bedload was much larger during the surge than in the pre-surge. Field observations of stream \#2 concluded that several of the "water-discharge events" recorded (automatically) between 1 and 14 June were actually stream-surface elevation increases caused by bed aggradation rather than water-discharge increases. On 12 June, an apparent high-water discharge (water-surface elevation increase) was visually observed. There may, in fact, have been a slight decrease in water discharge, but there was a major increase in bedload and channel aggradation. Estimates of bedload were made by observing the time taken for the construction of various aggradational features: fans, depression infillings and valley fillings. Some estimates were for short-lived, extreme bedload events, but the best estimate of the general bedload was the time taken to infill a relic ice-collapse hole in the stagnant ice of the old moraines. This hole was part of the drainage route of stream \#2. The hole (approximately $150 \mathrm{~m}$ diameter, with vertical walls) took $3 \mathrm{~d}$ to fill with sediment to a depth of about $5 \mathrm{~m}$. This mass of sediment (about $10^{8} \mathrm{~kg}$ ) included a large quantity of cobbles and gravels, which moved as bedload, along with finer material which may have been moving as suspended load. This means that $4 \times 10^{2} \mathrm{~kg} \mathrm{~s}^{-1}$ of material was trapped in the hole. The water flowed out of the hole by going under the stagnant ice and could not be sampled, but appeared to be very turbid and still carrying much of the suspended load. The suspended load in stream \#2 was about $2 \times 10^{2} \mathrm{~kg} \mathrm{~s}^{-1}$. Therefore the bedload-transport rate must have been in excess of $2 \times 10^{2} \mathrm{~kg} \mathrm{~s}^{-1}$, and the amount of bedload probably exceeded the rate of suspended-load transport. This high rate of bedload occurred only during the peak months of the surge, mainly June and July 1983. Ratios of bedload to suspended load of $0.3: 1.0$ are reported elsewhere (Drewry, 1986), and are probably more typical of the non-surge Variegated streams. Taking into account this bedload transport, and adding the suspended-load transport, the total equivalent erosion during the surge was $>0.2 \mathrm{~m}$, possibly closer to $0.3 \mathrm{~m}$, of bedrock from under the area of the glacier.

Variegated Glacier has been under observation at times of widely differing basal sliding velocities. The sediment-output and ice-velocity records allow comparison of the sediment ouput with the sliding velocity. This comparison is complicated by the time variation of the output-sediment flux and the time and space variations of glacial-sliding velocity. A comparison of the sediment output with glacier motion can be obtained by comparing the instantaneous stream-sediment load with some measure of the glacier speed. For example, in the final weeks of the surge Figure $6 \mathrm{~d}$ and $6 \mathrm{a}$ can be compared. There is only a weak relationship. In contrast, a comparison of Figure 6c and a shows a good correlation between the sediment concentration and glacier velocity $7 \mathrm{~km}$ above the terminus, at least for the period before 7 July.

At any time, basal sliding velocity varies over the area of the glacier bed, but because sediment output represents some sort of averaging of the output over the glacier, it is appropriate to use an averaged basal sliding velocity. An average velocity based on partitioning of the glacier into six regions of assumed homogeneous velocities was used with an area-weighted average. The sediment output varies diurnally, unrelated to sliding velocity; it also varies seasonally, correlating only poorly with basal sliding. Ideally, the sediment output should be integrated over a long enough period to span diurnal, synoptic weather and seasonal cycles, but there are not enough data. Therefore, a period in each of the years of observation was chosen that spanned several weeks, had good data and occurred at the same seasonal time; the second half of June, from 1980 to 1983, was chosen. 
Humphrey and Raymond: Hydrology, erosion and sediment in a surging glacier

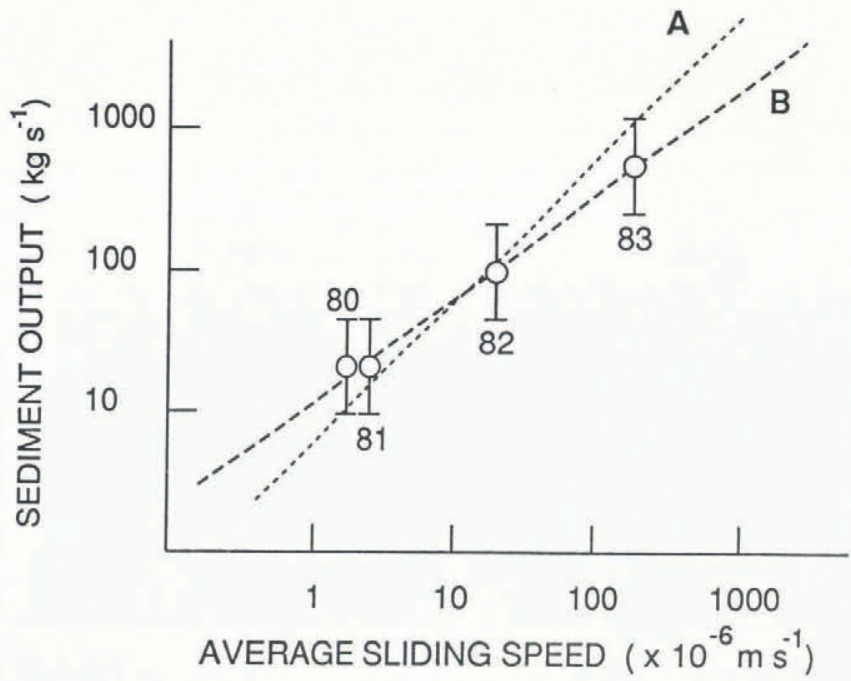

Fig. 8. Suspended-sediment output versus glacier-sliding speed. Line $B$ shows the best-fit line. Line $A$ shows a linear relationship that corresponds to a dimensionless erosion rate of $10^{-4}$.

Figure 8 shows the rate of evacuation of suspended sediment from Variegated Glacier, plotted against the glacier-surface velocity (a surrogate for sliding velocity). The error bars indicate factors of $2(+100 \%$ to $-50 \%)$ on this $\log$ - log plot. Line B is the best-fit line, with a slope of 0.8 . Line $\mathrm{A}$ has a slope of 1 and is also within the error bars. Figure 8 shows a simple correlation between icesliding speed and quantity of sediment output and in the following discussion a linear relationship (i.e. line A) is assumed, although any power between 0.6 and 1.0 is allowed by the data. If there were no variations in the debris stored in the glacial system, then the rate of sediment evacuation would be a measure of the net erosion rate under the glacier. However, changes in storage of debris under the glacier would create a difference between the erosion rate and the sedimentevacuation rate. Indeed, the elevated-sediment output of the streams in the year following the surge implies that some material eroded during the surge goes into temporary storage and is not flushed out during the surge. However, considering the amount of debris mobilized by the surge, significant changes in storage beneath the glacier would imply a shift from a "dirty" bed of mixed rock with minor till patches to a bed of considerable till thickness, i.e. a deformable bed. There has been no indication from drilling that the bed was deformable, so we conclude that sediment output is a good indicator of basal erosion under Variegated Glacier even on month- or year-long time-scales.

Drewry (1986) summarizes data on erosion rates for glaciers, inferred from sediment output, and finds a range for non-surging glaciers of $0.1-30 \mathrm{~mm} \mathrm{a}^{-1}$. Variegated Glacier in the pre-surge phase would lie within this range, with an erosion rate of $3 \mathrm{~mm} \mathrm{a}^{-1}$. During the peak of the surge, when the suspended-sediment concentration of the outlets of Variegated Glacier was much higher than typical for non-surging glaciers, the sediment output was at least an order of magnitude more than most glaciers. The equivalent erosion rate for the month of June 1983
Table 3. Dimensionless erosion rates (erosion rate divided by ice velocity)

\begin{tabular}{|c|c|c|c|}
\hline Locality & $\begin{array}{c}\text { Abrasion rate } \\
\mathrm{mm} \mathrm{a}^{-1}\end{array}$ & $\begin{array}{c}\text { Ice velocity } \\
\qquad \mathrm{m} \mathrm{a}^{-1}\end{array}$ & Erosion rate \\
\hline $\begin{array}{l}\ddagger \text { Glacier } \\
\text { d'Argentière }\end{array}$ & $<36$ & 250 & $1.4 \times 10^{-4}$ \\
\hline $\begin{array}{l}\text { Breidamerkur- } \\
\text { jokull }\end{array}$ & $\sim 2.5$ & 15 & $1.6 \times 10^{-4}$ \\
\hline † Variegated Glacier & - & - & $1.0 \times 10^{-4}$ \\
\hline
\end{tabular}

was $400 \mathrm{~mm} \mathrm{a}^{-1}$, more representatively $30 \mathrm{~m}$ per month.

The dimensionless-equivalent erosion rate, given by the ratio of equivalent erosion rate to ice velocity, as deduced in Figure 8, can be used to compare sediment production and erosion at Variegated Glacier with other glaciers. Table 3 lists local abrasion rates found by Boulton (1974) in experiments under two glaciers and includes the dimensionless-equivalent erosion rate for Variegated Glacier. The inference from Table 3 is that the erosion rate at Variegated Glacier is well within the range of values seen in non-surge glaciers, if account is taken of the high sliding velocity. Indeed, assuming that Figure 8 implies a linear relationship between sliding distance and erosion, then it also implies that Variegated Glacier dissipates a constant fraction of its flow energy in erosion, independent of sliding speed.

\section{Sediment-particle size}

The outlet streams and sediment samples showed a color shift from dark green-grey to light green-grey as the glacier moved from the pre-surge to the surge phase. The color continued to lighten as the surge progressed. By 1984, the sediment color had returned to dark grey. The color shift accompanied what appeared to be an increasing amount of fines in the samples. This subjective impression was quantified by size analysis of eight samples using Sedigraph and Horriba (Capa-500) settling velocity analyzers.

Size analyses are presented in Table 4 and Figure 9, which show the amount of silt-clay sized particles in the water samples. The samples were truncated at $50 \mu \mathrm{m}$ and the fine fraction was analyzed and expressed as a fraction of the total sample. Some fractionation of the samples may have occurred in the original sampling procedure, but such a fine-sized fraction should have had only small concentration gradients in the stream and have been equally well-sampled regardless of stage, sample location or even sample technique. Included in Table 4 are estimates of the ice-sliding speed at the time the sample was taken, for the area of the glacier that is thought to have contributed most of the sample. For example, the mini-surge sample (D) is associated with the ice speed in the mini-surge zone and is assigned a sliding velocity of $\geq 1.0 \mathrm{~m} \mathrm{~d}^{-1}$, even though the glacier below the mini-surge 
Table 4. Size analysis of representative sediment samples

\begin{tabular}{lccc} 
Month, year & $\begin{array}{c}\text { Fraction less than } \\
3 \mu m\end{array}$ & $\begin{array}{c}\text { Fraction less than } \\
1 \mu m\end{array}$ & $\begin{array}{c}\ddagger \text { Ice } \\
\text { velocity } \\
\mathrm{m} \mathrm{d}^{-1}\end{array}$ \\
& $\%$ & $\%$ & \\
\hline June 1984 & 23 & 3 & $<\sim 0.1$ \\
June 1981 & 40 & 6 & $0.1-3$ \\
Sept. 1983 & 44 & 9 & $<\sim 0.1$ \\
June 1980 & 50 & 12 & ${ }^{\dagger} 1-3$ \\
July 1982 & 53 & 13 & $\sim 3$ \\
June 1983 & 56 & 16 & $\sim 30$
\end{tabular}

$\ddagger$ Area weighted average for month.

${ }^{\dagger}$ Mini-surge ice motion velocity.

zone had a sliding velocity well below $0.1 \mathrm{~m} \mathrm{~d}^{-1}$. From Table 4 , it is seen that the ordering of the samples with respect to the amount of fines is the same as the ordering of glacier-sliding speed. This implies that the glacier releases proportionately more fine than coarse sediment as it slides faster.

The exception to the above order is the sample from 2 months after the surge (September 1983), which is richer in fines than the general trend would suggest. However, the June 1984 sample taken a year after the surge has few fines. It is interesting to note that the June 1984 sample is similar in size distribution to a water sample taken in the summer of 1976 from stream \#1 by W.D. Harrison (unpublished data). The 1984 data and the 1976 sample are probably representative of the size distribution while the glacier moves slowly. An association of fine particle size with high ice speed has also been observed during the surge of West Fork Glacier, Alaska (Benedict and others, 1990).

Storage of sediment in the basal zone complicates interpretation of the size variation in the samples. However, storage would need to be size-selective and the storage size would need to vary with sliding speed to invalidate the correlation between size and sliding speed seen in Table 4 . The erratic sediment load of the outlet stream does imply that short-term storage of sediment (on the order of days) occurs in the basal zone of the glacier. Storage of turbid water for hours or days could lead to sorting by partial settling in the cavities of a linkedcavity-type distributed water-flow system. This is a mechanism for both size-selective and sliding-sensitive storage, at least in the short term. However, since the bulk of the basal sliding, sediment output and probably basal erosion occurs during the peak months of the surge, the erosion process must produce a size distribution not very different from that sampled during the peak of the surge, regardless of whether there is size sorting. If there is any size-selective storage through the surge cycle, then storage of finer sizes has to occur at slower sliding speeds.

The storage scenario of the previous paragraph makes sense only if the distributed linked-cavity flow system which is thought to exist during the surge (Kamb and others, 1985) tends to store coarse and evacuate fines,

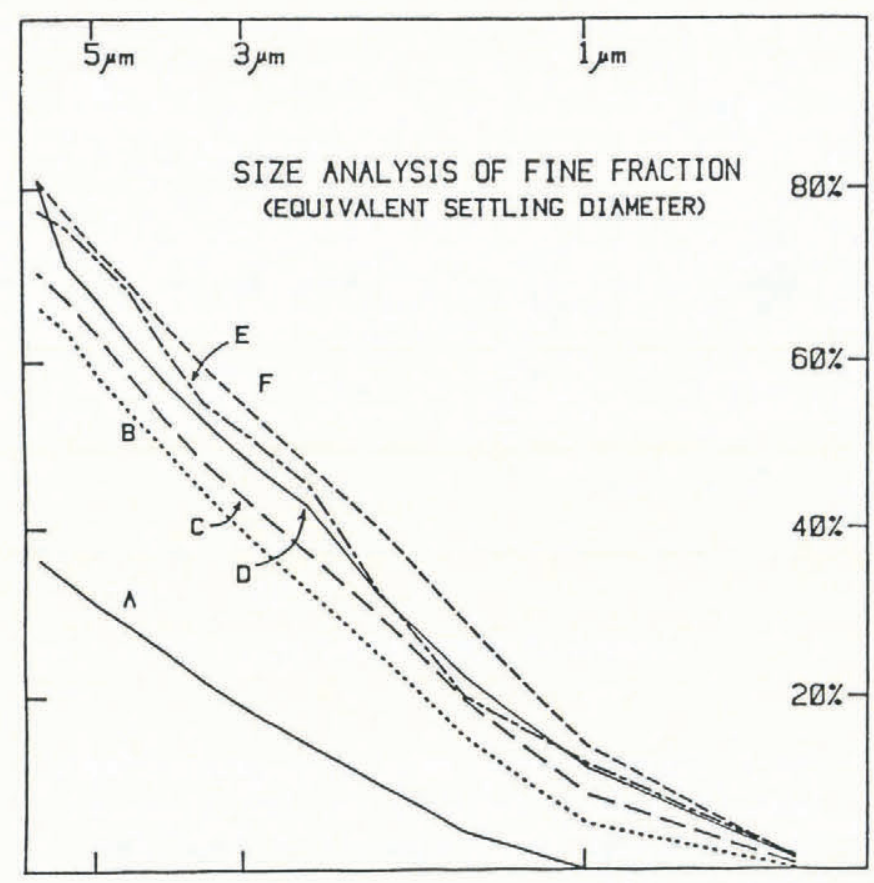

Fig. 9. Sediment particle-size distribution in samples from stream \#1. The fraction is plotted as percentage of sample finer than the given size, and the samples were truncated above $50 \mu \mathrm{m}$. Curve A, June 1984, sliding velocity $<0.1 m d^{-1}$; curve B, June 1981, sliding velocity 0.1$0.3 m^{-1}$; curve $C$, September 1983, sliding velocity $<\sim 0.1$ md $^{-1}$; curve D, fune 1980 (mini-surge), sliding velocity $1-3 m d^{-1}$; curve E, July 1982, sliding velocity $\sim 3 \mathrm{md}^{-1}$; curve $F$, June 1983, sliding velocity $\sim 30 \mathrm{md}^{-1}$.

while the conduit system which is important during the quiescent phase of motion tends to remove the coarse material. The linked-cavity system could be a storage system for the coarser fraction of the sediment since it has low water velocities, and the conduit system would erode the coarse fraction with its high-velocity water flow, although for the erosion to be significant the conduit system would have to traverse large areas of the bed during the quiescent phase of glacier flow. Lateral movement of the basal conduit system has been observed at some glaciers, in particular Bondhusbreen in Norway and Gornergletscher and Glacier d'Argentière in the Alps. The above discussion is inconclusive, but we feel that, despite some storage and sorting by size, the data show a strong trend toward finer erosion products at faster sliding speeds.

Increase in the output of fine material as the sliding velocity increases implies the erosional processes produce more fine-grained material at faster sliding velocities. Theories of basal abrasion (Hallet, 1979) do not include any relation between basal velocity and particle size. Some subglacial erosion features, in particular chatter marks (Gilbert, 1906), may indicate a length scale that depends on the rate of loading, which in turn implies that some aspects of erosion are sensitive to sliding speed. Basal abrasion is not well understood and the size effects found here may provide new clues about the process.

Eight samples were analyzed under a scanning electron microscope to observe sediment shapes and sizes. The samples showed that the size distribution of 
the lithic fragments appears continuous well into the submicron size range. All particles appear to be angular rockand-crystal fragments with no evidence of rounding or attrition; they are similar to the most angular samples shown by Whalley and Langway (1980) and Lister (1981).

\section{DISCUSSION}

\section{A model of the basal system under the surge zone}

In a previous paper (Humphrey and others, 1986) it was concluded that the basal system in the pre-surge phase consisted of two flow regions separated by a transition zone. The lower glacier was underlain by a high watervelocity conduit or conduit system, while the upper reaches of the glacier were underlain by a distributed-flow region characterized by slow water velocity and large average cross-sectional area for water flow, such as would be found in a linked-cavity system. As the melt season advanced, the distributed system in the upper glacier gave way to a conduit system, so that by the end of the melt season a conduit existed under most of the glacier. At the onset of winter, the water system collapsed into a distributed system that underlay the glacier (at least above $\mathrm{Km} \mathrm{10}$ ) by the beginning of the next melt season.

Data presented in this paper support a similar view of the subglacial system during the surge, with the difference that the transition between the conduit system and the distributed system is located by the surge front and moves down-glacier. Of particular interest is the water resistivity record for 1982 and 1983 (Figs 4e and 6e). Resistivity is well described by dilution of basal water with surface meltwater (Humphrey and others, 1986). Meltwater input is diurnal, and for a diurnal signal to exist in the stream the total lag time for water-flux transfer, from the highest zone in which meltwater is an important input to the basal system, must be less than $1 \mathrm{~d}$. Throughout 1982 there was a strong diurnal signal, indicating that at least the lower half of the glacier had a fast-water system. As the surge front moved into the lower glacier in 1983 the diurnal signal in resistivity died out. By the time of the surge peak in June 1983 there was no diurnal signal. As pointed out above, this implies that the flow velocity of the water behind the surge front was of order $0.15 \mathrm{~m} \mathrm{~s}^{-1}$ or less. Within a week of the surge termination on 5 July, a growing diurnal signal is seen in the water resistivity, implying the rapid establishment of a conduit system through the stalled surge front and up the glacier. This picture is compatible with the subglacial water velocities measured with two dye injections by Brugman (1986) and reported in Kamb and others (1985).

A speculative but consistent description of the basal hydraulics of Variegated Glacier through its surge cycle can be given. During the quiescent phase of glacier motion, the subglacial hydraulic system consists of an annual dynamic balance between conduit development, which is caused by the flush of meltwater of the ablation season, and the collapse of the conduit system into a linked (possibly poorly linked) cavity system as a result of the lack of melt in winter (Raymond, 1987). In the spring, the glacier is underlain by a tunnel system beneath its lower part and a distributed system of passages in the upper part. Mini-surges occur in the upper part that is underlain by the distributed-flow system, and are stopped in their down-glacier propagation by the transition from distributed to confined basal-water flow. The mini-surge "season" is terminated by the development of a tunnel under the upper glacier. In the surge phase of motion, there are also waves of rapid sliding. These die out as they propagate down-glacier toward the tunnel zone as in the case of the mini-surges; however, during the surge the distributed-flow system encroaches down-glacier with the propagating surge front. At the peak of the surge the distributed-flow system underlies most of the glacier. However, the transition zone from distributed to tunnel flow becomes narrower as the surge front steepens, and the surge front is eventually breached by a tunnel system. After the surge there is evidence of the drainage of either subglacial or englacial storage, which may represent the collapse of the distributed-flow system and the creation of a tunnel drainage under the lower glacier. The now quiescent glacier is reset for the start of another surge cycle.

\section{CONGLUSIONS}

Our picture of the basal hydraulic system concludes that low basal-water velocities predominate behind the surge zone (also noted by Brugman, 1986). The high velocities of water below the surge front imply the existence of a conduit system under the slower-moving, non-surging ice. Glacier sliding was related to basal hydraulics; in particular, velocity slow-downs were correlated with the release of large amounts of water. Over $1 \mathrm{~m}$ of water volume was stored per unit area during the surge, much of it englacially. This implies a strong relationship between sliding and water storage. Furthermore, the volume of storage implies that the relationship between sliding and the basal hydrologic system is between sliding and volume of water, not necessarily between sliding and basal water pressure.

The erosion rate during the surge was extreme in comparison to non-surging glaciers, but directly proportional to the high sliding velocity. Indeed, the sediment output of Variegated Glacier can be characterized as directly proportional to the basal sliding. A dimensionless erosion rate (meters eroded from the bed divided by meters of sliding) for Variegated Glacier is of the order of $1.0 \times 10^{-4}$. This erosion rate is comparable to other glaciers and suggests that this form of dimensionless erosion measure may be useful for comparisons between glaciers. Total erosion during the 20 year surge cycle was on the order of $0.3 \mathrm{~m}$ of bedrock, with approximately twothirds occurring during the 2 years of the surge peak, and the bulk during the peak 2 months. High sediment concentrations in the streams lyear after the surge indicate incomplete flushing of eroded sediment and imply memory in the sediment-storage system.

\section{ACKNOWLEDGEMENTS}

This study formed part of the first author's Ph.D. 
dissertation, and was carried out under the auspices of the Variegated Glacier research program of C.F. Raymond (University of Washington) and W.D. Harrison (University of Alaska). Many thanks are extended for field help to G. Anderson, M. Balise, T. Johansen, M. Magnussun, T. Pfeffer and L. Sinear. The work was supported by U.S. National Science Foundation grants DPP-7903942 and DPP-8200725 to the University of Washington.

\section{REFERENCES}

Benedict, R. J., C. F. Raymond, K. Echelmeyer, W. Harrison and E. Chacho. 1990. Hydrological observations and implications of the West Fork Glacier surge, Alaska. EOS, 71(43), 1315.

Boulton, G.S. 1974. Processes and patterns of glacial erosion. In Coates, D. R., ed. Glacial geomorphology. Binghamton, NY, State University of New York, 41-87.

Brugman, M.M. 1986. Water flow at the base of a surging glacier. (Ph.D. thesis, California Institute of Technology, Pasadena, CA.)

Collins, D.N. 1978. Hydrology of an Alpine glacier as indicated by the chemical composition of meltwater. Z. Gletscherkd. Glazialgeol., 13(1/2), 1977, 219-238.

Collins, D.N. 1979. Sediment concentration in melt waters as an indicator of erosion processes beneath an Alpine glacier. 7. Glaciol., 23(89), 247-257.

Collins, D. N. 1981. Seasonal variation of solute concentration in melt waters draining from an Alpine glacier. Ann. Glaciol., 2, 11-16.

Drewry, D. 1986. Glacial geologic processes. London, Edward Arnold.

Fountain, A.G. 1992. Subglacial water flow inferred from stream measurements at South Cascade Glacier, Washington, U.S.A. $\mathcal{F}$. Glaciol., 38(128), 51-64.

Gilbert, G. K. 1906. Crescentic gouges on glaciated surfaces. Bull. Geol. Soc. Am., 17, 303-313.
Hallet, B. 1979. A theoretical model of glacial abrasion. F. Glaciol., 23(89), 39-50.

Harrison, W. D., C. F. Raymond and P. MacKeith. 1986. Short period motion events on Variegated Glacier as observed by automatic photography and seismic methods. Ann. Glaciol., 8, 82-89.

Humphrey, N., C. Raymond and W. Harrison. 1986. Discharges of turbid water during mini-surges of Variegated Glacier, Alaska, U.S.A. J. Glaciol., 32(111), 195-207.

Kamb, B. and H. Engelhardt. 1987. Waves of accelerated motion in a glacier approaching surge: the mini-surges of Variegated Glacier, Alaska, U.S.A. J. Glaciol., 33(113), 27-46.

Kamb, B. and 7 others. 1985. Glacier surge mechanism: 1982-1983 surge of Variegated Glacier, Alaska. Science, 227(4686), 469-479.

Leopold, L. B., M. G. Wolman and J. P. Miller. 1964. Fluvial processes in geomorphology. San Francisco, CA, N. H. Freeman and Co.

Lister, H. 1981. Particle size, shape, and load in a cold and a temperate valley glacier. Ann. Glaciol., 2, 39-44.

Raymond, C. F. 1987. How do glaciers surge? A review. F. Geophys. Res., 92(B9), 9121-9134.

Raymond, C.F. and S. Malone. 1986. Propagating strain anomalies during mini-surges of Variegated Glacier, Alaska, U.S.A. J. Glaciol., 32(111), 178-191.

Raymond, C., T. Jóhannesson, T. Pfeffer and M. Sharp. 1987. Propagation of a glacier surge into stagnant ice. F. Geophys. Res., 92(B9), 9037-9049.

Tranter, M. and R. Raiswell. 1991. The composition of the englacial and subglacial component in bulk meltwaters draining the Gornergletscher, Switzerland. J. Glaciol., 37(125), 59-66.

Whalley, W.B. and C.C. Langway, Jr. 1980. A scanning electron microscope examination of subglacial quartz grains from Camp Century core, Greenland - a preliminary study. J. Glaciol., 25(91), $125-131$.

The accuracy of references in the text and in this list is the responsibility of the authors, to whom queries should be addressed. 